\title{
Tax policy in the system of post COVID-19 anti-crisis measures
}

\author{
Viacheslav Shavshukov ${ }^{1, *}$, and Natalia Zhuravleva ${ }^{2}$ \\ ${ }^{1}$ 190031, Russia, Saint Petersburg, Institute of Independent Social Economic Investigations, 4 \\ Efimova St. \\ ${ }^{2}$ 190031, Russia, Saint Petersburg, Emperor Alexander I St Petersburg State Transport University, 9 \\ Moskovsky pr.
}

\begin{abstract}
Research Background: Tax policy and reforms are the means to overcome the COVID-19 crisis, contributing to economic growth. The study is based on an analysis of tax regimes before the pandemic.

Purpose of the article: Purpose of the article is to develop instruments of tax regulation in anti-crisis tax policy.

Methods: The analysis employs macroeconomic indicators from the IMF, and WB databases. The comparative analysis of countries in terms of Total Tax and Contribution Rate (TTCR), Labour Tax TTCR, other taxes TTCR has been conducted on the basis of WB/PWC tax ranking methodology. The paper presents a classification of tax systems according to six rankings, and suggests tax policy modifications.

Findings \& Value added: The main directions of tax policy reform are: 1) The tax system should maintain its progressive character while increasing social equity, a new quality of economic growth and life. 2) Income taxation is less conducive to economic growth than consumption taxation. The study suggests differentiation in tax policies for developed and developing countries. 3) The choice between a flat and a progressive personal income tax scale should be made on the bases of the thorough analysis of the tax systems of countries leading in the quality of life. Their regimes can serve as a benchmark. 4) The taxation of interest, dividends and capital gains under dual treatment is a promising tax policy direction. 5) Reforming the CIT on the basis of differentiated rental income would allow for part of the income to costs and part to profits.
\end{abstract}

Keywords: COVID-19 crisis; anti-crisis tax policy; tax and investment regimes ranking

JEL Classification: $H 2 ; F 3 ; E 6$

\footnotetext{
* Corresponding author: shavshukov@rambler.ru
} 


\section{Introduction}

In the post COVID-19 crisis environment, fiscal policy and tax reform focus on achieving economic growth targets and benchmarks: quality of life, and green, digital, robot-assisted, and sustainable economy.

\section{Concept and methods}

The research background of the study is based on a systematic analysis of the tax regimes of countries around the world before the COVID-19 pandemic. The study is based on data collection methods, and a comparative country-by-country analysis of tax policies provided by international and national financial institutions. Tax policies are ranked according to the TTCR indicator prepared by the WB/PwC. The research suggests the direction of tax reform in the post-COVID-19 period through the lens of social justice, equity, economic growth and quality of life.

\section{Results}

\subsection{Tax systems ranking}

The tax system is crucial for economic growth and investment decisions. The World Bank Group and PricewaterhouseCoopers' (PwC) annual ranking of tax systems (Paying Taxes) of 190 countries from 2004 to 2019 was used (Table 1). The purpose of the ranking is to measure the tax burden, and the ease of calculating and paying taxes. The study includes such indicators as Total Tax and Contribution Rate (TTCR). TTCR consists of Profit tax TTCR, Labour tax TTCR, Other taxes TTCR; and Labour cost of tax accounting - time in hours required to meet the requirements of calculation, preparation of returns for the principal taxes; and the number of tax payments.

Table 1. Corporate tax burden by region and country, if not specified \%, global ranking, 2018, 2019

\begin{tabular}{|l|c|c|c|c|c|}
\hline \multicolumn{1}{|c|}{ Regions/Unions/States } & TTCR & $\begin{array}{c}\text { Profit } \\
\text { TTCR } \\
\text { taxes, \% }\end{array}$ & $\begin{array}{c}\text { Labour } \\
\text { TTCR } \\
\text { taxes, \% }\end{array}$ & $\begin{array}{c}\text { Other } \\
\text { TTCR } \\
\text { taxes, \% }\end{array}$ & $\begin{array}{c}\text { Global } \\
\text { Ranking } \\
\mathbf{2 0 1 9}\end{array}$ \\
\hline South America & 52.6 & 17.2 & 14.5 & 18.9 & \\
\hline Africa & 47.1 & 18.3 & 15.3 & 13.2 & \\
\hline EU average & 39.6 & 12.4 & 25.5 & 1.7 & \\
\hline North America & 38.9 & 19.1 & 16.1 & 3.7 & \\
\hline Asia Pacific & 38.4 & 17.5 & 10.8 & 8.1 & \\
\hline Central Asia \& Eastern Europe & 33.4 & 12.7 & 17.8 & 2.9 & \\
\hline World average, 2019 & 40.4 & 21.7 & 16.9 & 7.1 & \\
\hline Bahrain & 33.8 & 0.0 & 13.5 & 0.3 & 1 \\
\hline Hong Kong SAR China & 21.9 & 16.5 & 5.3 & 0.1 & 2 \\
\hline Qatar & 11.3 & 0.0 & 11.3 & 0.0 & 3 \\
\hline Ireland & 26.0 & 12.4 & 12.2 & 1.4 & 4 \\
\hline Kuwait & 13.0 & 0.0 & 13.0 & 0.0 & 6 \\
\hline UAE & 15.9 & 0.0 & 14.1 & 1.8 & 30 \\
\hline Denmark & 24.2 & 17.7 & 3.8 & 2.7 & 8 \\
\hline Finland & 36.6 & 12.1 & 23.0 & 1.5 & 10 \\
\hline Oman & 27.4 & & & & 11 \\
\hline S. Korea & 33.2 & 18.2 & 13.7 & 1.4 & 12 \\
\hline Israel & 25.3 & 18.0 & 5.8 & 1.5 & 13 \\
\hline
\end{tabular}




\begin{tabular}{|l|c|c|c|c|c|}
\hline Canada & 24.5 & 8.0 & 12.7 & 3.8 & 19 \\
\hline Switzerland & 26.8 & 9.3 & 17.7 & 1.8 & 20 \\
\hline Netherland & 40.7 & 20.5 & 19.8 & 0.4 & 22 \\
\hline USA (2019) & 36.6 & 20.7 & 9.89 .8 & 6.1 & 25 \\
\hline U.K. (2019) & 30.6 & 16.6 & 12.0 & 2.0 & 27 \\
\hline Australia & 47.4 & 26.1 & 21.0 & 0.3 & 28 \\
\hline Cyprus & 22.4 & 8.3 & 13.0 & 1.1 & 29 \\
\hline Sweden & 49.1 & 13.1 & 35.4 & 0.6 & 31 \\
\hline Norway & 36.2 & 20.0 & 15.9 & 0.3 & 34 \\
\hline Spain & 46.9 & 10.6 & 35.6 & 0.5 & 35 \\
\hline Taiwan China & 36.8 & 14.7 & 18.7 & 3.4 & 39 \\
\hline Germany & 48.9 & 23.2 & 21.4 & 4.3 & 41 \\
\hline Austria & 51.8 & 17.0 & 34.2 & 0.6 & 44 \\
\hline Japan & 46.7 & 23.9 & 18.6 & 4.2 & 51 \\
\hline RSA & 29.2 & 21.8 & 4.0 & 3.4 & 54 \\
\hline Russia & 46.2 & 7.4 & 36.6 & 2.2 & 58 \\
\hline France & 62.2 & 0.7 & 51.1 & 10.4 & 61 \\
\hline Malaysia & 38.7 & 10.6 & 16.7 & 2.5 & 80 \\
\hline Indonesia & 30.1 & 18.1 & 11.6 & 0.4 & 81 \\
\hline India & 49.7 & 21.6 & 20.2 & 7.9 & 115 \\
\hline Italy & 59.1 & 14.6 & 42.9 & 1.6 & 128 \\
\hline China & & & & & \\
2018 & 67.3 & 11.1 & 48.1 & 8.1 & \\
\hline Brazil & 59.2 & 6.3 & 46.2 & 6.8 & 130 \\
\hline
\end{tabular}

Source: World Bank Group. Paying Taxes 2018 data; PwC "Paying Taxes 2020": overall ranking and data tables.

The tax system is assessed in terms of two functions: fiscal and incentive for economic development, investment, and growth in aggregate supply (AQS). The economic policy of the state for each economic cycle opts for a specific combination between taxation of profits, labour, other taxes and levies, ultimately determining the total tax burden on business. The tax system and policies are a sophisticated tool for accelerating or restraining economic growth, and stimulating national capital and/or foreign investment in the country. These methodological considerations are the basis for the analysis of the statistical data in Table 1.

In 2018, the global average total TTCR tax burden amounted to 40,4\%. It ranged from $25-50 \%$ in developed economies (around $40 \%$ on average) and $39-59 \%$ in developing countries. Meanwhile, the most attractive economies had a TTCR of 22-33\%. By contrast, the tax burden in the world's leading emerging economies (China, India, and Russia) was more substantial and amounted to $59,2 \%, 49,7 \%$ and $46,2 \%$, respectively.

The global average rate of Profit TTCR taxes (\%) amounted to 21,7\%, with developed economies averaging 15,7\%, Asia-Pacific, Central Asia and Eastern Europe 15,8\%. Rates in Russia and China were extremely competitive, accounting for $7,3 \%$ and $6,2 \%$ of the total tax burden, respectively. These countries ranked alongside Switzerland (9,3\%), Ireland $(12,4 \%)$ and Sweden $(13,1 \%)$. Corporate income tax in Russia was $20 \%$, USA - 21, China - $25 \%$.

Labour taxation (Labour TTCR taxes, \%) accounted for 36,6\% of Russia's total tax burden, in China - 46,2\%, compared to a global average rate of 16,3\%. In South America tax levied 14,5\%, in Central Asia and Eastern Europe 12,7\%, in the Asia-Pacific region 17,8\%, in North America 16,1\%, in the EU countries 25,5\%. Labour tax rates stood at 37\% in China, $30 \%$ in the Russian Federation versus Germany 21,5\%, Canada 12,7\%, the US 7,65\%, England 12\%, and Kazakhstan 10,1\% (Trading Economics China, 2019; Trading Economics United States, 2019). Thus, labour taxation as a share of the total tax burden for China and Russia remains too high and is the weakest element in the tax system of these countries. 
Time required for tax remission is a constituent part of the financial costs of tax regulation. Between 2006 and 2019, there has been significant improvement worldwide towards reducing the time required for tax reporting and payment. In Europe and Central Asia, the time has shortened from 434 hours to 174 hours, respectively, in East Asia and the Pacific (from 299 to 177), Latin America (from 416 to 325), OECD countries (from 230 to 162), the Middle East and North Africa (from 332 to 285), and South Asia (from 274 to 268).

The global economy between 2013 and 2020 demonstrated stability in the tax burden: TTCR 38,8\%, Profit taxes 17,3\%, Labour taxes 18,3\%, Other Taxes 3,1\%. Tax burden increased in 2018 only in four countries: Ghana (from 32\% to 55\%), Guinea (from $61 \%$ to $69 \%$ ), Mali (from $48 \%$ to $54 \%$ ), Italy (from $53 \%$ to $59 \%$ ). Four countries lowered their tax burden, in line with the global trend of the 21 st century: Romania (from $40 \%$ to $20 \%$ ), Gambia (from $57 \%$ to $48 \%$ ), USA (from $43,8 \%$ to $36,6 \%$ ), China (from $64,0 \%$ to $59,2 \%$ ).

The key tax issue for foreign investment capital is cumulative TTCR, labour taxation, ease of procedures and time to pay taxes (including time for VAT refunds), and the number of payments. The tax system and TTCR have a significant impact on MNCs' investment decisions, the investment climate and the attractiveness of the economy for FDI. The analysis showed that there is some correlation between the tax system (TTCR, tax accounting effort, number of tax payments), a country's investment policy and FDI. The research includes a ranking of tax systems and an assessment of their investment policies (see Table 2).

Table 2. Tax systems and investment policies, 2018-2019

\begin{tabular}{|c|c|c|c|}
\hline $\begin{array}{l}\text { Tax system and tax } \\
\text { policy rankings }\end{array}$ & $\begin{array}{l}\text { TTCR, } \\
\%\end{array}$ & $\begin{array}{c}\text { Countries, } \\
\text { position in the global ranking } \\
\text { of tax systems (in brackets) }\end{array}$ & $\begin{array}{c}\text { Characteristics of } \\
\text { countries' investment } \\
\text { policies }\end{array}$ \\
\hline $\begin{array}{c}\text { Global average rate } \\
\text { TTCR, \% }\end{array}$ & 39 & & \\
\hline $\begin{array}{c}\text { A-rating } \\
\text { High tax burden }\end{array}$ & $40-60$ & $\begin{array}{l}\text { Africa, Brazil (184), } \\
\text { PRC (130), Russia (58), } \\
\text { India (50) } \\
\text { Austria, France (61), Spain, } \\
\text { Germany (41), the Netherlands }\end{array}$ & $\begin{array}{l}\text { Countries with a focus on } \\
\text { the fiscal function of the } \\
\text { tax system. } \\
\text { Countries interested in } \\
\text { FDI, but with a rigid tax } \\
\text { system and an } \\
\text { unfavourable investment } \\
\text { climate. } \\
\text { Countries with a } \\
\text { conservative tax system. } \\
\text { Investment policies focus } \\
\text { on national capital rather } \\
\text { than FDI. }\end{array}$ \\
\hline $\begin{array}{c}\text { B-rating } \\
\text { Moderate tax } \\
\text { burden }\end{array}$ & $35-40$ & $\begin{array}{l}\text { EU, USA (36), OECD, Taiwan } \\
\text { (39), Vietnam (109), Asia- } \\
\text { Pacific countries, Malaysia (80) }\end{array}$ & $\begin{array}{l}\text { Countries, traditionally } \\
\text { attractive for investment, } \\
\text { with favourable fiscal } \\
\text { policies. Countries that } \\
\text { combine fiscally optimal } \\
\text { functions with sustainable } \\
\text { economic development } \\
\text { using FDI. } \\
\text { FDI-focused countries. }\end{array}$ \\
\hline $\begin{array}{c}C \text {-rating } \\
\text { Soft tax burden }\end{array}$ & $30-35$ & $\begin{array}{l}\text { Central Asia, Eastern Europe, } \\
\text { UK (23), Bahrain (1) }\end{array}$ & $\begin{array}{l}\text { FDI-focused countries, } \\
\text { encouraging faster } \\
\text { economic growth and the } \\
\text { acquisition of modern } \\
\text { technology and and } \\
\text { management systems. }\end{array}$ \\
\hline
\end{tabular}




\begin{tabular}{|c|c|c|c|}
\hline & & & $\begin{array}{l}\text { The UK pursues a liberal } \\
\text { financial policy to serve as } \\
\text { the world's centre of } \\
\text { eurocurrencies. }\end{array}$ \\
\hline $\begin{array}{c}\text { D-rating } \\
\text { Soft taxation }\end{array}$ & $25-30$ & $\begin{array}{l}\text { Bahrain, Ireland (4), Indonesia, } \\
\text { Israel (13), Oman (11), South } \\
\text { Africa, Bahrain, Vietnam, } \\
\text { Malaysia, Thailand, Switzerland } \\
\text { (20) }\end{array}$ & $\begin{array}{l}\text { Countries with soft } \\
\text { taxation focusing on: } \\
\text { - direct investments } \\
\text { (Indonesia, Vietnam, } \\
\text { South Africa, Malaysia, } \\
\text { Thailand), } \\
\text { - portfolio investments } \\
\text { (Switzerland) } \\
\text { - tax revenues from } \\
\text { offshore registration of } \\
\text { companies as tax residents } \\
\text { (Ireland) }\end{array}$ \\
\hline $\begin{array}{c}\text { E-rating } \\
\text { Liberal tax regime }\end{array}$ & $20-25$ & $\begin{array}{l}\text { Hong Kong (2), Denmark (8), } \\
\text { Cyprus (29), Singapore (7), } \\
\text { Canada (19) }\end{array}$ & $\begin{array}{l}\text { Aggressive investment } \\
\text { policies. Special economic } \\
\text { zones }\end{array}$ \\
\hline $\begin{array}{c}\text { F-rating } \\
\text { Ultra-low tax rates }\end{array}$ & $\begin{array}{c}\text { below } \\
20\end{array}$ & Kuwait (6), Qatar (3), UAE (30) & $\begin{array}{l}\text { Aggressive investment } \\
\text { policies. Special economic } \\
\text { zones }\end{array}$ \\
\hline $\begin{array}{l}\text { China } \\
\text { Russia }\end{array}$ & $\begin{array}{l}59,2 \\
46,2\end{array}$ & & \\
\hline
\end{tabular}

Source: compiled by the authors.

A-rated countries focus on the fiscal function of the tax system. Some of them (China, Russia, Brazil) are additionally interested in FDI. These economies are attractive for FDI because of their huge domestic markets. OECD countries with conservative tax systems are oriented towards domestic capital rather than FDI. B-rated countries are classified as developed economies and some developing economies. The first group are classic investment-attractive countries with moderate tax policies. They have an optimal balance between fiscal functions and sustainable economic development through FDI. The second group is with a focus on FDI. The tax and investment policy rankings are presented in Table 2. What draws attention is the pattern - the lower the total tax burden (TTCR) is, the softer are the tax policies and the more liberal investment regimes for Domestic and Foreign Direct Investments are.

\subsection{Concepts and approaches to tax policy reform}

The fundamental principle underlying the tax system, namely, its progressive nature (the tax burden increases with the income/wealth of the taxpayer), is to be preserved. However, it should be complemented by other aspects: gender equality, a fair distribution of resources across generations and people living in similar environments. A new quality of sustainable economic growth requires taxes that minimise negative impacts on savings, investment and consumption, production of surplus value and employment. The tax system should stimulate the production of GDP and its fair distribution. This is consistent with the conclusions of Acosta Ormaechea et al. (2012) and Arnold et al. (2011) that "excessive" taxation of income is detrimental rather than conducive to long-term economic growth. The average global rate of corporate income tax for the period from 1990 to 2020 has decreased by half from $40 \%$ to $20 \%$. Moreover, income taxes can reduce inequality even more than consumption taxes. The highest degree of professionalism of tax authorities in conducting a reform is to find a compromise, a balance between economic growth and fiscal capacity. The art of such a 
balance lies not only in controlling rates, but also in modifying the tax base. An IMF study showed that expanding the revenue base of the most widely collected tax, VAT, would be less detrimental to growth than increasing the rate itself (IMF, 2015).

The final shape of tax reform depends on the current content and traditions of fiscal policy, the level of personal and business incomes, the structure of the economy, the size of the shadow economy, and the efficiency of tax administration. It is possible for all countries to use tax policy to achieve more comprehensive growth, but there are significant limitations. Developed economies are more adaptive to progressive taxation of individuals, they are more relaxed about corporate income taxation, environmental carbon taxes, inheritance and estate taxation, and have a wider VAT base. Developing economies have significant potential in administration, tax collection, simplification of the VAT system, wider use of taxation of the extractive sectors, and property and environmental taxes. Despite the strategic undesirability of consumer taxation, emerging market economies can apply it in the post-COVID period, but should direct these taxes towards social programmes related to education, primary health care and infrastructure sectors that directly improve the quality of life.

\subsubsection{Labour taxation}

On the one hand, personal income tax is relatively easy to collect, but on the other hand, it encourages the authorities to introduce a progressive scale to realise the principle of fairness. Despite widespread public support for the idea of fair taxation, high tax rates do not seem to serve as incentives for higher productivity, higher incomes, or additional vocational training for more demanding and higher-paid work. Moreover, high rates and a progressive labour taxation scale underlie tax evasion.

Personal income tax exemption. The principles of fairness and progressivity imply exemptions. However, approaches to the tax threshold and tools of implementation vary considerably. A tax credit is more progressive than a tax deduction or a zero rate. It all depends on the tax rate: in developed economies it is $25 \%$ of average wage, in developing economies it is over $30 \%$. Often the tax rate thresholds are higher than the average wage. As a result, tax collection is low and taxes are targeted at high incomes. The solution lies in setting a threshold value in a range between a reasonable minimum rate and the average wage.

Progressive scale of personal income tax. The choice between a flat rate (applied in 30 countries) and a progressive rate is determined by the balance each country has between ensuring the reproduction of the labour force, fairness and fiscal efficiency. From this point of view, a flat rate in the range of $10-15 \%$ is less efficient than a progressive scale of personal income tax. A sharp transition from one scale to the other may lead to a fall in tax collection, so building a tax culture should be accompanied by gradual increases in the threshold rate, on the one hand, and a mild progressive tax and taxable income, on the other. The criteria include the collectability of taxes and the targeted social nature in which funds from progressive taxes are used. The Benchmark is the tax policies (rates, regimes) of the countries with the highest quality of life.

The maximum personal income tax rates are dictated by the income level, the interest of the authorities in collecting the maximum tax revenues, and the propensity of the population to be fair through a progressive income scale. In the developed economies, the highest average marginal rate is about $50 \%$, the lowest average is $20 \%$. In developing economies, the highest average rate is $30 \%$, the lowest $10 \%$. The strategy of advanced economies is, firstly, to maintain or to increase personal income tax on a very selective basis. Secondly, the progressive rate should be stratified. In developing economies, it is possible to move towards more progressive taxation by increasing the income scale to 3-4 thresholds and bringing the maximum rate to $35-40 \%$. Tax credits for low-paid workers under special programmes of 
state banks and lower social security payments can be used to dampen the tax burden. This practice has had a significant social impact in a number of countries during the COVID- 19 .

\subsubsection{Capital tax on individuals}

In a rapidly developing financial market, the taxation of dividends, interest and capital gains (Capital Gains Tax, CGT) looks promising. There is a choice of two options. The first is a 'flat tax' - taxation of earned income and capital gains on a progressive scale. Its implementation tends to raise tax administration problems and there is a difficulty in separating labour and capital taxation for the self-employed. The second option involves double taxation of personal income depending on its type: personal income tax is taxed on a progressive scale, while capital income is taxed on a fixed but soft scale. In most countries, higher rates are applied to dividends and capital gains than to bank interest income.

The CGT rate should obviously be less than the maximum tax rate in the progressive personal income tax scale of the country. For example, in developed countries the PIT averages $50 \%$, with the CGT being half as high and ranging from $24-30 \%$. The more developed the financial market is, the greater is the differentiation of approaches and rates.

\subsubsection{Corporate income tax (CIT)}

This tax is a part of income tax and an important source of budgetary revenue. A pandemic, being a force majeure, affects businesses and the labour market in different ways. The COVID pandemic has shown that tourism sector companies have made minimal profits or losses, while pharmaceutical giants, pharmacy chains, and highly digitalised companies have increased their revenues and profits. The CIT affects the earnings of companies, shareholders and the workforce, as it sets lower wages. However, when CIT is calculated on a differential rent basis, as profits above the minimum income, the tax will directly affect property owners and investors and can be redistributed progressively. A rent-based CIT permits income below the minimum threshold to be charged to costs and a portion to profits. Such approach to CIT is more conducive to companies oriented towards economic growth as a hedge against increased environmental risks and force majeure (pandemic). It also reduces borrowing against tax payments and defaults.

What are the directions for reform regarding the CIT? The global practice of tax competition has already established a worldwide trend to reduce the CIT from $40 \%$ in 1990 to $20-25 \%$ in 2021 . Small, high-tech economies have lower rates $(2-22 \%)$ and low-income emerging economies have higher rates (30\%) (Aslam and Coelho, 2021). The rates are likely to be frozen or increase (e.g. from $21 \%$ to $28 \%$ in the US).

\subsubsection{Consumption tax}

Taxes levied on consumption are difficult to make progressive and equitable, but they are the most important source of government revenues, and are easy to collect and administer. VAT (or sales tax) exists in almost every country in the world, accounting for $30 \%$ of all taxes and over $6 \%$ of world GDP (in developed high-income economies it is over 7\% of GDP, in lowincome developing economies 5\%). The ease of administration makes it possible to collect up to $50-60 \%$ (Keen, 2013, p.4). What are the directions for VAT reform? First, a move towards a flat rate (the current global average rate is 15\%) (Keen, 2013, p.5) would increase tax collection. Spending on services and food in household income in developing economies is higher than in developed economies, so reducing VAT will increase demand, revenue, and the volume of VAT. Secondly, a drastic reduction in the range of rates (which is too high (3$27 \%)(\mathrm{OECD}, 2020)$, which will facilitate administration, reduce costs and, hopefully, make 
businesses more compliant with the tax law. Third, the VAT exemption undermines tax refund (credit, reimbursement) for the companies purchasing production resources (input VAT). Fourth, the threshold of revenue (turnover) for VAT registration should be lowered for IT companies and e-commerce businesses (the number of which has increased in the pandemic).

Excise duties. The practice of levying excise duties is widely practiced and driven by external negative effects of products: some food is a threat to health and life expectancy; oil and petroleum products and packaging destroy the ecological balance. Excise duties are easy to administer because they are part of the goods and services that are sold. They generate 1.5$2.5 \%$ of GDP and since the global crisis of 2008-2009 have been on the rise in low-, middleand high-income countries. The global practice of excise tax administration has shown that it should be oriented to the product structure rather than to threshold cost of goods.

Environmental taxes (as a response to environmental externalities) have become particularly concerning since the Paris International Climate Agreement on Climate, 2015 and Leaders' Climate Summit (2021). The $\$ 75 /$ tonne carbon tax aims to reduce greenhouse gas emissions by at least 55\% from 1990 levels by 2030, as well as reduce global greenhouse gas emissions to pay for social costs. They meet the principles of the Paris Agreement and could generate $1-2 \%$ of GDP.

\section{Discussion}

Tax policy have always been the subject of extensive research by global academia and international financial institutions. At its conferences, the IMF draws on the results of academic research to develop recommendations for adjusting tax policies in different countries. The IMF conference (2021) "Minimum and digital taxation: consensus or divide?" focused on two pressing issues: 1) Taxation in the digital economy and 2) The rationale for an effective global minimum tax. The nature of the discussion was conditioned by the large income gap between developed and developing economies. The conference then served as a consensus-building forum. Gugeri, Kana and Ocampo considered the options for national legislatures of low-income countries to respond to this tax competition, based on an analysis of the impact of the global tax on income and investment. Wei Cui, A. Munanda, M. Lennard, M. Grostein discussed the procedural issues of Article 12b of the UN International Tax Compact for developing Countries (IMF, April 2021).

The IMF conference "Advancing the Evaluation of Tax Reforms", April 26, 2018, had a significant historiographical impact in the current global reform, at which the IMF's Fiscal Affairs Department (FAD) presented a thorough thirty-year analytical and statistical retrospective of tax reform outcomes in 23 developed and emerging market economies (IMF, April 2018). A particular interest in light of the current search for the potential of taxes in the post-COVID world economy is the study by F. Lima "The Macroeconomic Effects of Tax Changes", Mertens "The Near Term Growth Impact of the Tax Cuts and Jobs Act", Vuletin "Non-linear Effects of Tax Changes on Output: The Role of the Initial Level of Taxation". Both studies emphasised that tax reforms have played an active role in supporting growth even when interest rates were low and fiscal policy was restricted. The works of P. Dallari "Do Financial Markets React to Tax Policy Announcements?" and Slemrod, Kawano 'A Cross-Country Examination of Tax Systems Changes: New Evidence from a Novel Database' showed the effectiveness of changes in the tax base in addition to tax rates. Such historiographical works have always been very relevant, as confirmed by the study (Greenspan, 2005) on the US tax code system reforms of 1954, 1969, 1986.

The tax impact has not only been the subject of macroeconomic analysis, but also of sectoral analysis. The effect of taxes on banks' liability structure through the leverage lens has been examined by Gambacorta, et al. (2017). Improved legal environment and tax 
administration provide an important contribution to tax reform. This point has been substantiated by many studies, in particular by Bilek, et al. (2021), which found these factors to present a serious obstacle to the development of small and medium-sized agricultural enterprises in the Czech Republic (sample from the Ceske Budejovice region). The practical analysis by Vyugin, (2003) focuses on the coordination of monetary, budget and tax policies.

Since 2016, the OECD has produced annual surveys on Tax Policy Reforms: OECD and Selected Partner Economies, which provide a comprehensive comparative analysis of tax policies. The study "Tax Policy Reforms 2020: OECD and selected Partner Economies" addresses such issues as "Tax reforms before COVID-19 Crisis" in OECD countries, Argentina, Indonesia and SRAs, and fiscal anti-crisis measures (OECD Tax reforms, 2020). The surveys include a detailed analysis of changes across the tax structure focusing on social contribution: Personal income tax, Corporate income tax and other corporate taxes, VAT and other taxes on goods and services, Environmentally related taxes, Property taxes.

\section{Conclusion}

Tax concepts, regimes and goals constitute an important component of tax policy. The analysis of these policies in the global economy prior to the COVID-19 pandemic has identified general areas of tax policy reform, which was the main focus of the article.

1) The existing tax system should remain progressive. At the same time, its impact on social equity, the equitable distribution of wealth and a new quality of economic growth and life should be enhanced. New external environments such as climate change and pressing environmental problems should be incorporated into its agenda in the shortest possible time.

2) Rankings of tax systems show that the lower TTCR, the more lenient the tax policy, the more liberal and attractive the investment regime for domestic and foreign capital.

3 ) Income taxation is less conducive to economic growth than consumption taxation. At the same time, there is a need for a differentiated approach. Developed economies with high incomes concentrate on progressive systems of personal taxation, high corporate taxation, and broadening the VAT base. Developing economies focus on labour taxation, taxes on extractive industries, and targeted use of tax revenues in social programmes.

4) Tax policy should be selected based on the tax systems of the leading countries in terms of quality of life, especially when choosing between a flat and a progressive personal income tax scale. Their regimes can serve as a benchmark. The strategy for developed economies is to stabilise rates and tie them to social strata. In developing countries, it is possible to move towards a gradual increase in rates.

5) Given the rapid growth of the financial markets and the diversity of instruments, taxing interest, dividends and capital gains is a promising option, but using a double regime: personal income tax on a progressive scale, capital gains on a fixed scale.

6) Reforming CIT on the basis of differentiated rental income would allow charging some part of the income below the minimum threshold to costs and another part to profits. Such approach to CIT is more conducive to the economic growth of companies, as it hedges against heightened risks in the external environment, and eventually reduces borrowing for taxes and in the event of defaults. It is necessary to develop a special tax regime for companies extracting hydrocarbons and minerals on the basis of a rent-based approach.

7) Reducing VAT and introducing a flat rate would increase tax collection. Spending on services and food in household incomes is higher in developing economies than in developed ones, so a reduction in VAT would increase demand, and the amount of tax collected. 


\section{References}

1. Acosta Ormaechea, S., \& Yoo, J. (2012) Tax Composition and Growth: A Broad CrossCountry Perspective. IMF Working Paper WP/12/257.

2. Arnold, JM., Brys, B., Heady, C., Johanson, A., Schwellnus, C., \& Vartia, L. (2011). Tax Policy for Economic Recovery and Growth. The Economic Journa, 121, 59-80.

3. Aslam A., \& Coelho M. (2021). The Benefits of Setting a Lower Limit on Corporate Taxation. IMFBlog. https://blogs.imf.org/2021/06/09/the-benefits-of-setting-a-lowerlimit-on-corporate-taxation/

4. Bilek, S., Kmecova, I., \& Tlusty, M. (2021). The impact of taxes and administrative activities of SMEs on their performance. SHS Web of Conf., 92.

5. Gambacorta, L., Ricotti G., Sundaresan S., \& Wang Z. (2017). BIS Working Paper No 611. The effects of tax on bank liability structure. Bank for international settlements.

6. Greenspan, A. (2005). The tax system. BIS Review, 14.

7. IMF conference (April 13, 2021). Minimum and digital taxation: Consensus or divide? $I M F / W B G$ spring meeting. Conference on International taxation. https://www.imf.org/en/News/Seminars/Conferences/2021/03/01/international-taxconference

8. IMF conference (April 26, 2018). Advancing the evalution of tax reforms. IMF Conference and database launch. Washington, DC. https://www.imf.org/en/News/Seminars/Conferences/2018/03/08/evaluating-taxreforms

9. IMF Policy Paper. Fiscal Policy and Long-Term Growth. (2015). IMF.

10. Keen, M. (2013). The Anatomy of the VAT. IMF Working paper. 13.

11. Leaders Summit on Climate (2021). https://www.state.gov/leaders-summit-on-climate/

12. OECD (2020). Consumption Tax Trends 2020: VAT/GST and Excise Rates, Trends and Policy Issues. OECD Publishing, Paris.

13. OECD (2020). Tax Policy Reforms 2020: OECD and Selected Partner Economies. Chapter 3. Tax reforms before the COVID-19 crisis. https://www.oecdilibrary.org/sites/7af51916-en/1/3/3/index.html?itemId=/content/publication/7af51916en\&_csp_=8a96f5eedbc1947f715e $8 \mathrm{fc} 47 \mathrm{~d} 48 \mathrm{f} 410 \&$ itemIGO $=$ oecd\&itemContentType $=$ book

14. Overall ranking and data tables. (2020). Paying Taxes 2020. PwC. https:/www.pwc.com/gx/en/services/tax/publications/paying-taxes-2020/overallranking-and-data-tables.html

15. Paying Taxes 2018. (2018). World Bank Group. PwC. https://www.doingbusiness.org/content/dam/doingBusiness/media/SpecialReports/2018-Paying-Taxes.pdf

16. Trading economics. China (2019). https://radingeconomics.com/china/calendar

17. Trading economics. United States (2019). https://tradingeconomics.com/unitedstates/calendar

18. Vyugin, O. (2003). Budget and tax problems and central banks: Russia's experiences. BIS Papers No 20. 